\title{
Toxic Multinodular Goitre (Thyrotoxicosis with Hyperthyroidism) Induced Cardiomyopathy: A Case Report
}

\author{
Sahil N. Fulara*, Nasir Y. Fulara \\ Department of Medicine, Jaslok Hospital and Medical Research Center, Mumbai, India \\ Email: ${ }^{\star d r s a h i l . f u l a r a @ g m a i l . c o m ~}$
}

How to cite this paper: Fulara, S.N. and Fulara, N.Y. (2017) Toxic Multinodular Goitre (Thyrotoxicosis with Hyperthyroidism) Induced Cardiomyopathy: A Case Report. Open Journal of Clinical Diagnostics, 7, 67-72.

https://doi.org/10.4236/ojcd.2017.72007

Received: April 19, 2017

Accepted: June 18, 2017

Published: June 21, 2017

Copyright ( 92017 by authors and Scientific Research Publishing Inc. This work is licensed under the Creative Commons Attribution International License (CC BY 4.0).

http://creativecommons.org/licenses/by/4.0/

\begin{abstract}
Introduction: Toxic multinodular goitre, first described by H.S. Plummer in 1913, is unremitting and often develops slowly, with more subtle symptoms than Graves' disease. Cardiac symptoms such as tachycardia, heart failure, or arrhythmia and atrial fibrillation are most frequent. Here we describe a case who presented with symptoms of thyroid enlargement and heart failure. Case report: A 48-year old female presented to us with complaints of dysphagia, hoarseness of voice, breathlessness on exertion and palpitations since one month ago. Furthermore, the patient gave history of swelling of the neck which was initially pea sized and gradually increased to the current size over a period of two months. On examining the swelling of the neck, thyroid gland appears enlarged, firm with multiple nodules. Two-dimensional echocardiography revealed a dilated left ventricle with generalized hypokinesia. Computed Tomography of the neck suggested enlarged thyroid gland $(12.1 \mathrm{~cm} \times$ $6.5 \mathrm{~cm}$ ) with heterogenous architecture, and thyroid gland encircling the trachea for approximately 270 degree with mass effect. Thyroid scan showed multinodular goitre with multiple hyperfunctioning nodules of both lobes and warm nodules only in left lobe. The patient was diagnosed as multinodular goitre with cardiomyopathy. The patient was treated medically with methimazole, propranolol, aspirin, ramipril, sustained release urodeoxycholic acid, rosuvastatin, pantoprazole and multivitamin. The patient underwent near total thyroidectomy with radioactive iodine ablation, as and when required. Conclusion: Patients with toxic multinodular goitre very frequently present with cardiovascular symptoms, which when identified and treated early can reduce the morbidity significantly.
\end{abstract}

\section{Keywords}

Cardiomyopathy, Dysphagia, Goitre, Thyroid 


\section{Introduction}

Toxic adenoma and toxic multinodular goitre are the second most common causes of hyperthyroidism, after Graves' disease [1]. Toxic multinodular goitre, first described by H.S. Plummer in 1913, is unremitting and often develops slowly, with more subtle symptoms than Graves' disease [2]. When the functional capacity of the thyroid follicular cells becomes independent of regulation by thyroid-stimulating hormone (TSH) focal and/or diffuse hyperplasia of thyroid follicular cells occurs, a long phase of subclinical hyperthyroidism can precede the appearance of overt symptoms. Cardiac symptoms such as tachycardia, heart failure, or arrhythmia and atrial fibrillation are most frequent. Here we describe a case, who presented with symptoms of thyroid enlargement and heart failure.

\section{Case Report}

A 48-year old female presented to us with complaints of difficulty in swallowing food since two months and hoarseness of voice since one and half month. She also complained of breathlessness on exertion and palpitations since one month. Patient was apparently alright one month back, when she complained of difficulty in swallowing food more with solids than liquids. On further inquiry, patient gave history of swelling of the neck which was initially pea sized and gradually increased to the current size over a period of two months (see Figure 1). Patient also noticed hoarseness of voice over a period of one and half month after the swelling had set in.

Patient also complained of breathlessness on exertion since one month along with history of palpitation. There was no history of chest pain, syncope, orthopnea, paroxysmal nocturnal dyspnoea, weight loss, tremors, anxiety and diarrhea. The past medical history of the patient has been uneventful with no history of any major illness/surgery.

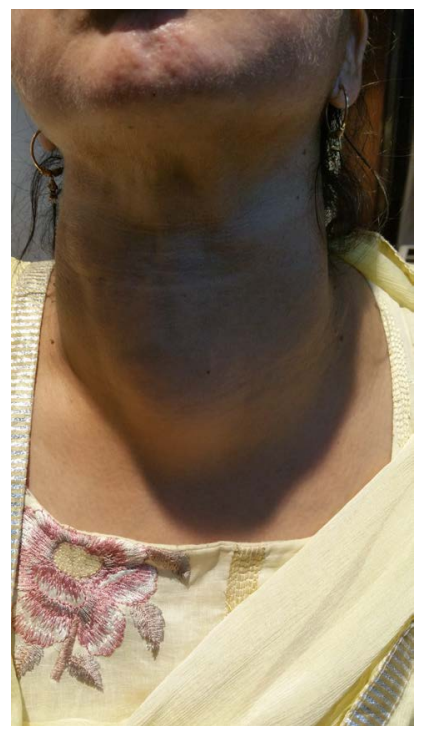

Figure 1. Thyroid swelling of the patient. 
On examining the patient, there was no evidence of pallor, icterus, clubbing, cyanosis or lymphadenopathy. On examining the swelling of the neck, thyroid gland appeared enlarged, firm with multiple nodules. Pulse of the patient was noted at $92 / \mathrm{min}$ and blood pressure was $124 / 80 \mathrm{~mm}$ of mercury. There were no other significant clinical findings systemically. The patient underwent routine hematological investigations like complete blood count, liver enzymes, electrolytes, serum calcium and vitamin D levels, and thyroid profile. We also sent the patient for ultrasound abdomen, which was suggestive of mild hepatomegaly with fatty changes and cholelithiasis. Two-dimensional echocardiography revealed a dilated left ventricle with generalized hypokinesia. Left ventricular ejection fraction was $35 \%$ and also showed reduced left ventricular systolic functions. Computed Tomography of the neck suggested enlarged thyroid gland $(12.1 \mathrm{~cm} \times 6.5 \mathrm{~cm})$ with heterogenous architecture, and thyroid gland encircling the trachea for approximately 270 degree with mass effect. Thyroid scan showed multinodular goitre with multiple functioning, fair functioning nodules of both lobes and warm nodules only in left lobe. The patient was diagnosed as multinodular goitre with cardiomyopathy.

The patient was advised total thyroidectomy in view of enlarged thyroid gland with mass effect compressing the trachea. The patient was treated medically with methimazole, propranolol, aspirin, ramipril, sustained release urodeoxycholic acid, rosuvastatin, pantoprazole and multivitamin. The patient showed improvement with symptoms but was eventually referred for surgical management. The patient underwent near total thyroidectomy with radioactive iodine ablation if and when required. We obtained consent of the patient while the patient was admitted for writing up and publishing the case.

\section{Discussion}

Dilated cardiomyopathy (DCM) is defined by the prescence of dilated and poorly functioning left ventricles in the absence of abnormal loading conditions, sufficient to cause an overall impairement of systolic [3]. Majority of patients with DCM have no identifiable cause, thereby labelled as idiopathic DCM. However, an underlying etiology can be identified in a fraction of patients of DCM. Association of hyperthyroid state and cardiac morbidity is well established [4]. The high output state in thyrotoxicosis can result in cardiac failure, despite increased cardiac performance. Low output cardiac failure in hyperthyroid state is an extremely rare condition and there have been very few published reports of such cases [5]. Such patients, after receiving treatment, may have a complete recovery of cardiac function [6]. Our patient, who presented with features of heart failure, had an underlying hyperthyroid state, which if treated in a timely fashion may lead to recovery of cardiac function (Table 1).

In patients with hyperthyroidism, the cardiovascular system is altered by the thyroid hormone which has important effects on cardiac muscle, the peripheral circulation, and the sympathetic nervous system [7]. At the cellular level, the function of thyroid hormone is mediated by the binding of triiodothyronine 
Table 1. Results of hematological results.

\begin{tabular}{cc}
\hline Investigation & Reported levels (normal range) \\
Hemoglobin & $13.8 \mathrm{mg} \%(12-15.5 \mathrm{mg} \%)$ \\
Total leucocyte count & $4800(4000-10,000 / \mathrm{cumm})$ \\
Platelet & $2,35,000(150,000-450,000 / \mathrm{mL})$ \\
Blood Urea Nitrogen & $28 \mathrm{mg} / \mathrm{dl}(7-20 \mathrm{mg} / \mathrm{dl})$ \\
Serum creatinine & $0.8(0.5-1.1 \mathrm{mg} / \mathrm{dl})$ \\
Serum bilirubin & $1 \mathrm{mg} / \mathrm{dL}(0.2-1.2 \mathrm{mg} / \mathrm{dl})$ \\
SGOT & $30 \mathrm{U} / 1(7-40 \mathrm{U} / \mathrm{l})$ \\
SGPT & $34 \mathrm{U} / 1(5-50 \mathrm{U} / \mathrm{l})$ \\
Serum Calcium & $9.4 \mathrm{mg} / \mathrm{dL}(8.5-10.2 \mathrm{mg} / \mathrm{dl})$ \\
Serum Vitamin D & $32 \mathrm{ng} / \mathrm{mL}(2-32 \mathrm{ng} / \mathrm{mL})$ \\
Serum sodium level & $138 \mathrm{mEq} / \mathrm{L}(135-145 \mathrm{mEq} / \mathrm{L})$ \\
Serum potassium level & $4.2 \mathrm{mEq} / \mathrm{L}(3.5-5 \mathrm{mEq} / \mathrm{L})$ \\
Serum chloride level & $102 \mathrm{mEq} / \mathrm{L}(96-106 \mathrm{mEq} / \mathrm{L})$ \\
Random Blood Sugar & $98 \mathrm{mg} / \mathrm{dL}(79-140 \mathrm{mg} / \mathrm{dL})$ \\
Free T3 & $4.62(1.7-3.7)$ \\
Free T4 & $1.93(0.7-1.8)$ \\
Thyroid Stimulating Hormone & $0.07(0.45-4.5)$ \\
\hline
\end{tabular}

(T3) to its receptors. T3 is transported to the cardiac cells to perform its function. The subsequent expression of genes is regulated by the binding of the T3-receptor complexes to DNA. This is specifically important for those genes that regulate the calcium cycling in the cardiac cells [8]. It has been studied extensively that some actions of T3 on the cardiac cells produce clinical findings that are clinically similar to those of stimulation of beta-adrenergic receptors [9]. Incompletely understood mechanisms may explain some of the non-nuclear actions of T3. The mere ability of almost all beta blockers to relieve many symptoms of hyperthyroidism exemplifies the interaction between T3 and the adrenergic nervous system. This process may involve increase in the density of betaadrenergic receptor, increased expression of the guanine nucleotide-binding protein (G protein), and down-regulation of the cardiac-specific isoform of the adenylyl cyclase catalytic subunit [10]. Although it is uncertain that whether hyperthyroid humans have increased catecholamine sensitivity, however, it has been shown that the effects of T3 on the heart can occur independently of beta-adrenergic receptor stimulation.

Additionally, almost all measures of cardiac function, including left ventricular (LV) ejection fraction, the rate of ventricular pressure development, diastolic relaxation, and cardiac output, are increased in such patients.

Surgical therapy is often recommended after adequate preoperative preparation in patients with large goitres or obstructive manifestations. Patients with fixed, especially partially retrosternal, goitre should be considered for surgery because of the risk of more complete obstruction should hemorrhage into a 
nodule occur. In a retrospective series of 581 patients with multinodular goitre, $13 \%$ had symptoms of cervical compression (choking, dysphagia, dyspnea) [11]. The majority of the patients with compressive symptoms were treated with thyroidectomy rather than radioiodine. All of those who had thyroidectomy had reduction in gland size and compressive symptoms, compared with only $46 \%$ of those who were treated with radioiodine. However, when surgery is contraindicated, even significant obstructive symptoms can be relieved by adequate radioiodine therapy [12].

\section{Conclusion}

Our case report shows that in a patient with an endocrine disorder, findings of a careful medical history should be confirmed with a physical examination. Patients with toxic multinodular goitre very frequently present with cardiovascular symptoms, which when identified and treated early can reduce the morbidity significantly.

\section{References}

[1] Cooper, D.S. (2003) Hyperthyroidism. Lancet, 362, 459-468. https://doi.org/10.1016/S0140-6736(03)14073-1

[2] Hurley, D.L. and Gharib, H. (1996) Evaluation and Management of Multinodular Goiter. Otolaryngologic Clinics of North America, 29, 527-540.

[3] Elliott, P. (2000) Diagnosis and Management of Dilated Cardiomyopathy. Heart, 84, 106-112. https://doi.org/10.1136/heart.84.1.106

[4] Klein, I. and Danzi, S. (2007) Thyroid Disease and the Heart. Circulation, 116, 1725-1735. https://doi.org/10.1161/CIRCULATIONAHA.106.678326

[5] Goland, S., Shimoni, S. and Kracoff, O. (1999) Dilated Cardiomyopathy in Thyrotoxicosis. Heart, 81, 444. https://doi.org/10.1136/hrt.81.4.444

[6] Umpierrez, G.E., Challapalli, S. and Patterson, C. (1995) Congestive Heart Failure Due to Reversible Cardiomyopathy in Patients with Hyperthyroidism. The American Journal of the Medical Sciences, 310, 99-102. https://doi.org/10.1097/00000441-199531030-00003

[7] Klein, I. and Ojamaa, K. (2001) Thyroid Hormone and the Cardiovascular System. The New England Journal of Medicine, 344, 501-509. https://doi.org/10.1056/NEJM200102153440707

[8] Brent, G.A. (1994) The Molecular Basis of Thyroid Hormone Action. The New England Journal of Medicine, 331, 847-853. https://doi.org/10.1056/NEJM199409293311306

[9] Klein, I. (2012) Endocrine Disorders and Cardiovascular Disease. In: Bonow, R.O., Mann, D.L., Zipes, D.P., Libby, P., Eds., Braunwald's Heart Disease: A Textbook of Cardiovascular Medicine, 9th Edition, Elsevier Saunders, Philadelphia, 1829.

[10] Klein, I. and Danzi, S. (2007) Thyroid Disease and the Heart. Circulation, 116, 1725-1735. https://doi.org/10.1161/CIRCULATIONAHA.106.678326

[11] Porterfield Jr., J.R., Thompson, G.B., Farley, D.R., et al. (2008) Evidence-Based Management of Toxic Multinodular Goitre (Plummer's Disease). World Journal of Surgery, 32, 1278-1284. https://doi.org/10.1007/s00268-008-9566-0

[12] Huysmans, D.A., Hermus, A.R., Corstens, F.H., Barentsz, J.O. and Kloppenborg, 
P.W. (1994) Large, Compressive Goitres Treated with Radioiodine. Annals of Internal Medicine, 121, 757-762.

https://doi.org/10.7326/0003-4819-121-10-199411150-00005

Submit or recommend next manuscript to SCIRP and we will provide best service for you:

Accepting pre-submission inquiries through Email, Facebook, LinkedIn, Twitter, etc. A wide selection of journals (inclusive of 9 subjects, more than 200 journals)

Providing 24-hour high-quality service

User-friendly online submission system

Fair and swift peer-review system

Efficient typesetting and proofreading procedure

Display of the result of downloads and visits, as well as the number of cited articles

Maximum dissemination of your research work

Submit your manuscript at: http://papersubmission.scirp.org/

Or contact ojcd@scirp.org 